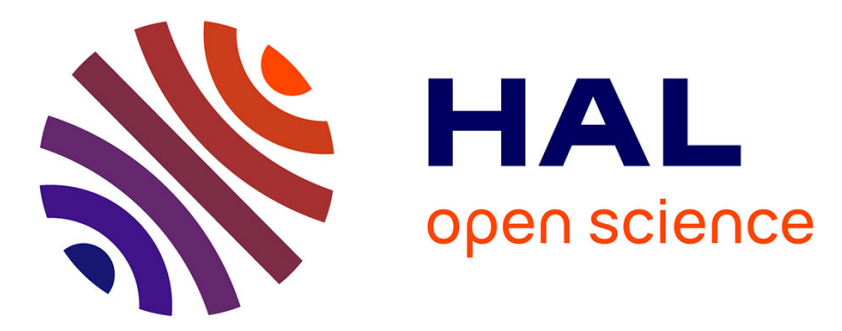

\title{
Magma influence on propagation of normal faults: Evidence from cumulative slip profiles along Dabbahu-Manda-Hararo rift segment (Afar, Ethiopia)
}

Stéphanie Dumont, Yann Klinger, Anne Socquet, Cécile Doubre, Eric Jacques

\section{- To cite this version:}

Stéphanie Dumont, Yann Klinger, Anne Socquet, Cécile Doubre, Eric Jacques. Magma influence on propagation of normal faults: Evidence from cumulative slip profiles along DabbahuManda-Hararo rift segment (Afar, Ethiopia). Journal of Structural Geology, 2017, 95, pp.48-59. 10.1016/j.jsg.2016.12.008 . hal-01862668

\section{HAL Id: hal-01862668 https://hal.science/hal-01862668}

Submitted on 27 Aug 2018

HAL is a multi-disciplinary open access archive for the deposit and dissemination of scientific research documents, whether they are published or not. The documents may come from teaching and research institutions in France or abroad, or from public or private research centers.
L'archive ouverte pluridisciplinaire HAL, est destinée au dépôt et à la diffusion de documents scientifiques de niveau recherche, publiés ou non, émanant des établissements d'enseignement et de recherche français ou étrangers, des laboratoires publics ou privés. 
1 Magma influence on propagation of normal faults: Evidence from cumulative slip profiles along Dabbahu-

2 Manda-Hararo rift segment (Afar, Ethiopia)

3

4 Stéphanie DUMONT ${ }^{1, *}$, Yann KLINGER $^{1}$, Anne SOCQUET $^{2}$, Cécile DOUBRE $^{3}$, Eric JACQUES $^{1}$

51 Institut de Physique du Globe de Paris, Paris Sorbonne Cité, Univ. Diderot, UMR7154-CNRS, Tectonique et

6 Mécanique de la Lithosphere, 1 rue Jussieu, 75005 Pairs, France. dmont.stephanie@gmail.com ; klinger@ipgp.fr ;

$7 \quad$ jacques@ipgp.fr

$8 *$ Now at Instituto Dom Luiz, University of Beira Interior, Covilhã, Portugal

92 Univ. Grenoble Alpes, ISTerre, F-38000 Grenoble, France. anne.socquet@univ-grenoble-alpes.fr

103 IPGS, Université de Strasbourg/EOST, CNRS 5 rue Descartes, F-67084 Strasbourg Cedex, France.

11 cecile.doubre@unistra.fr

12

13 Keywords:

14 Fault-slip profiles, normal faults, Afar, Manda-Hararo rift, magmato-tectonic interactions, fault growth

17 Abstract

Measuring displacement-length profiles along normal faults provides crucial information on fault growth processes.

19 Here, based on satellite imagery and topography we analyze 357 normal faults distributed along the active rift of

20 Dabbahu-Manda-Hararo (DMH), Afar, which offers a unique opportunity to investigate the influence of magmatism on

21 fault growth processes. Our measurements reveal a large variety of slip profiles that are not consistent with elastic

22 deformation. Their analysis contributes towards a better understanding of the lateral propagation of faults, especially

23 when nucleation points and existence of barriers are included. Using the fault growth model of Manighetti et al. (2001),

24 we determine the preferred direction of lateral propagation for each fault. Our results suggest that lateral propagation of

25 faults is easier away from areas where magma has been stored for long time at crustal depth, and has thus modified the

26 thermo-mechanical properties of the host-rock. However, these areas correspond also to areas where the initiation of

27 fault growth appears as easiest along the rift. In combining these results with the analysis of rift width and the position

28 of magma reservoirs along DMH rift, we show that fault growth keeps track of the magma presence and/or movement

29 in the crust. 


\section{Introduction}

Process of fault growth has been studied from earthquake surface ruptures as well as from cumulative slip profiles for various styles of tectonic deformation (Pollard and Segall, 1987; Walsh and Watterson, 1988; Cowie and Scholz, 1992a,b; Dawers et al., 1993; Bürgmann et al., 1994; Cartwright et al., 1995; Cowie and Shipton, 1998; Manighetti et al., 2001a, 2004, 2007, 2015; Scholz, 2002; Klinger, 2010). Most models are based on the elastic theory and for an isolated normal fault, they predict that slip should be maximum at the center of the fault and should tend towards zero at both ends of the fault trace, following an elliptical profile (Pollard and Segall, 1987; Cowie and Scholz, 1992a; Scholz, 2002). However, the numerous slip profiles measured from natural exposures, show a larger variety of patterns, with a first-order linear, and often, asymmetric shape (Muraoka and Kamata, 1983; Peacock and Sanderson, 1991; Bürgmann et al., 1994; Dawers and Anders, 1995; Nicol et al., 1996, 2010; Contreras et al., 2000; Manighetti et al., 2001a, 2004, 2015; Davis et al., 2005; Roche et al., 2012; Nixon et al., 2014; Tibaldi et al., 2016). Several mechanisms have been proposed to explain such a discrepancy between observations and model predictions. First, interactions of adjacent fault segments leading to the development of a main fault by segment linkage could cause a scattering of the cumulative slip along multiple fault traces (Cartwright et al., 1995; Dawers and Anders, 1995; Nicol et al., 1996, 2010; Fossen and Rotevatn, 2016). Second, the heterogeneity of the friction on the fault interface may contribute to the relaxation or concentration of stress along the fault plane and therefore locally stop or promote slip along the fault (Mikumo and Miyatake, 1978; Bürgmann et al., 1994). Third, interactions between faults, as well as crustal heterogeneities, act as barriers to fault propagation, promoting vertical fault growth instead (Aki, 1979; King, 1986; Manighetti et al., 2001a, 2004). In this latter case, the scarp height measurement represented as a function of the distance along the fault and called "displacement-length profile" or "slip profile", may thus be considered as a source of information regarding the conditions of lateral fault propagation and they can be used as a proxy to record the different phases of growth of a fault.

The Afar Depression is an ideal place to study the long-term evolution of normal faults because both low erosion and sedimentation make the normal faults well preserved, allowing for the use of the scarp height as a suitable measure of the cumulative slip. Manighetti et al. (2001a) used displacement-length profiles measured on normal faults dissecting the surface of the Afar depression to propose a model of fault growth based on the shape of profiles, especially those showing linear sections. The study of Manighetti et al. (2001a), however, did not take into account the potential influence of the magmato-tectonic interactions on the fault growth, whereas all the faults are located in a highly volcanic context. Indeed, the influence of magma bodies on the fault activity has been observed both at short and long time scales in Afar, and in other extensional regions (Mastin and Pollard, 1988; Rubin and Pollard, 1988; Rubin, 1992; Gudmundsson, 2003; Gudmundsson and Loetveit, 2005; Doubre et al., 2007; Doubre and Peltzer, 2007; Calais et al., 2008; Biggs et al., 2009; Medynski et al., 2013, 2016). Along the Dabbahu-Manda-Hararo (DMH) rift, in central Afar, 
magmato-tectonic interactions have been proved active for the last hundred thousand years (Lahitte et al., 2003a,b; VyeBrown, 2012; Ferguson et al., 2013; Medysnki et al., 2013, 2015, 2016). Using interferometric synthetic aperture radar analysis (InSAR) together with field observations, magmato-tectonic interactions have also been evidenced on the short-term, over the 5 years long-lasting rifting episode from 2005 to 2010, during both the dyking injections (Wright et al., 2006; Rowland et al., 2007; Grandin et al., 2009, 2010b; Hamling et al., 2009) and the few month-long post-dyking periods (Dumont et al., 2016).

DMH rift is in a late phase of magmatic continental rifting where dyke intrusions are assumed to be the main process for the nucleation and growth of normal faults (Carbotte et al., 2006; Rowland et al. 2007; Ebinger et al. 2013). Therefore, its past and recent magmato-tectonic activity makes it a good case study to examine the interplay between magmatism and faulting, and to investigate how faults propagate along an active magmatic rift. Here we use highresolution remote-sensing data and topography to map in detail normal fault scarps in the DMH rift and to measure cumulative throw along fault strike for 357 faults. By analyzing the shape of the displacement-length profiles as well as their distribution along DMH rift with respect to the magma reservoirs, we aim at better understand fault growth processes in presence of magma. More specifically we look how magma-induced heterogeneities in the crust can promote, or inhibit, lateral fault development. We also show that displacement-length profile for each fault can be used to track past magma injections.

81

\section{Geological Setting}

The Afar Depression is a diffuse triple junction where three divergent plate boundaries meet: the oceanic ridges of the Red Sea (RS), the Gulf of Aden (GA), and the East African Rift Systems (EARS) (Fig. 1a; Barberi and Varet, 1977; Tesfaye et al., 2003). On-land continuations of the GA and RS oceanic ridges are not yet connected and they overlap in central Afar (Courtillot et al., 1980, 1987; Tapponnier et al., 1990; Manighetti et al., 1997, 1998, 2001b). Along these two branches, active extension and recent volcanism are concentrated along rift segments, whose size and morphology are similar to those of second order segmentation of an oceanic slow-spreading ridge (Hayward and Ebinger, 1996;

89 Manighetti et al., 1998), although continental breakup is not yet clearly established in Afar (Makris and Ginzburg, 1987;

90 Tiberi et al., 2005; Hammond et al., 2011).

91 Insert Figure 1 The DMH rift belongs to the RS ridge (Fig. 1a). It consists in a $\sim 60 \mathrm{~km}$-long and $\sim 20 \mathrm{~km}$-wide volcano-tectonic

93 segment that localized faulting and volcanism since 1-1.5 Myr (Hayward and Ebinger, 1996; Manighetti et al., 2001b;

94 Lahitte et al., 2003b; Audin et al., 2004). The DMH rift segment concentrates most of the extension accommodating the 95 divergent motion of the Nubia and Arabia plates, which are moving apart at a rate of $15 \mathrm{~mm} / \mathrm{yr}$ (Fig. 1a; e.g. Vigny et al., 2006). Similar to other rift segments in Afar, the DMH encompasses a central volcanic center, the Ado'Ale Volcanic 
Complex (AVC) characterized by silicic rocks, which was intensely dismantled by large normal faults (Fig. 1b; Lahitte et al., 2003a,b). The location of the AVC corresponds to where the azimuth of the DMH rift axis and associated fault systems changes significantly. South of AVC, the main graben and normal faults are oriented $\sim$ N150 $0^{\circ}$, i.e. orthogonal to the $\mathrm{N} 055^{\circ}$-oriented Arabia/Nubia divergent plate motion. North of AVC, the faults and the rift inner graben are oriented N165 (Fig. 1b; Rowland et al., 2007; Medynski et al., 2013).

At its northern tip, the DMH rift hosts the $\sim 10 \mathrm{~km}$ in diameter Dabbahu stratovolcano (Fig. 1b). This volcano has participated in resurfacing the topography north of AVC, as suggested by extensive lava flows emitted 72-58 kyrs ago (Medynski et al., 2013). Geodetic and seismic data have shown that the Dabbahu, as well as the nearby Gabho volcano, were involved in the first and largest dyke intrusion ( $\sim 60 \mathrm{~km}$ long) of the 2005 rifting episode (Wright et al., 2006; Ayele et al., 2007; Grandin et al., 2009). The analysis of both historical eruptions and InSAR data following the September 2005 intrusion suggests the existence of a series of stacked sills located below the Dabbahu volcano, at depth ranging from 1 to $5 \mathrm{~km}$. Consistency of depth between the two approaches indicates that this magma storage could be a long-lived source (Field et al., 2012). During the rifting episode, the dykes injected between June 2006 and May 2010 were exclusively fed by the midsegment magma chamber (MSMC) located at the rift center, $\sim 5 \mathrm{~km}$ south of the intersection between the AVC chain and the rift axis, where the crust has been stretched and thinned down to $6 \mathrm{~km}$ (Keir et al., 2009; Hamling et al., 2009, 2010;

113 Grandin et al., 2010a, b; Belachew et al., 2011). Modeling of geodetic data spanning inter-dyking periods has suggested 114 that MSMC consisted both of a shallow magma chamber ( $\sim 4 \mathrm{~km}$ depth) and of a deeper one ( $>15 \mathrm{~km})$ (Grandin et al., 2010a; Hamling et al., 2009). Most of the smaller intrusions (at most $\sim 15 \mathrm{~km}$ long) propagated unilaterally towards either the northern or the southern end of segment (Hamling et al., 2009, 2010; Grandin et al., 2010b, 2011, 2012; Belachew et al., 2011, 2013), in a similar manner to what was observed during the Krafla rifting episode in Iceland (Björnsson et al., 1979; Wright et al., 2012). Normal faulting above dykes has been proposed to be the main process of seismic energy release during dyke intrusions (Belachew et al., 2013) and also to be responsible for the low-frequency earthquakes (Belachew et al., 2011; Tepp et al., 2016). Seismic analysis revealed that northward propagating dykes were

121 faster and more voluminous than southward propagating ones. Several mechanisms have been proposed to explain these 122 differences in the migration rates as resulting either from asperities associated with previous dyke intrusions, or 123 subcrustal magma chamber (Belachew et al., 2011), or an asymmetry in the distribution of tensile stresses along the rift 124 (Grandin et al., 2009, 2011; Barnie et al., 2015). In addition, MSMC refilled between dyke injections, inducing 125 significant transient surface displacements at the center of the rift (Grandin et al., 2010b) and triggering slip along the 126 surface faults during the months following the injections (Dumont et al., 2016). The lateral extension of the MSMC is 127 poorly constrained, although at first-order it should range between $5 \mathrm{~km}$ and $8 \mathrm{~km}$ along-axis (Grandin et al., 2010a; 128 Belachew et al., 2011). In addition to these reservoirs, the inversion of magneto-telluric data collected along a west-east 
profile located north of AVC has suggested the presence of a large magma reservoir located mostly off-rift, extending

$30 \mathrm{~km}$ to the west, ranging from 5 and $10 \mathrm{~km}$ in depth (Desissa et al., 2013).

\section{Materials and Method}

Using panchromatic Quickbird images (resolution $60 \mathrm{~cm}$, acquired between January 2006 and May 2007), SPOT-5 images (resolution 2.5 m, acquired between October 2005 and January 2006), a 10 m-accuracy DEM generated from SPOT-5 stereo images (resolution $20 \mathrm{~m}$ ) and InSAR data spanning the post-Sept. 2005 period (resolution $20 \mathrm{~m}$ ), faults were mapped along the DMH rift (Fig. 1b; Grandin et al., 2009; Dumont et al., 2016). Among this fault population, we only consider individual faults longer than $500 \mathrm{~m}$, in order to exclude incipient faults, and also because small scarps are falling into the limit of the vertical accuracy of the DEM. In addition, most of the short faults are located within the inner floor of the rift and may be partially covered by lava flows that would lead to a misinterpretation of their displacement-length profile. Following this criterion, our dataset is composed of 357 normal faults (Fig. 1b).

Using SPOT-5 DEM, we have extracted the cumulative vertical throw along strike for each fault in our dataset, by estimating the height of the scarp for a series of parallel short profiles normal to each fault strike, following the methodology described in Dumont et al. (2016). The scarp height represents therefore cumulative slip that includes the September 2005 intrusion and the centimeter-scale deformation until January 2006 induced by slow magma transfers (Dumont et al. 2016). The short profiles are separated by $\sim 15 \mathrm{~m}$, and the total number of profiles for each fault depends on the total length of the fault. Each profile for our fault population has been normalized using both their maximum displacement $\left(\mathrm{D} / \mathrm{D}_{\max }\right)$ and their maximum length $\left(\mathrm{L} / \mathrm{L}_{\max }\right)$ to be classified according to Manighetti et al. (2001a). These authors distinguished eight types of slip profile based on their shape, which are grouped into three main categories: unrestricted, restricted and elliptical profiles (Fig. 2). The scenario they proposed for fault growth takes into account the initiation point, where slip starts, and barriers, where propagation stops. The first-order linear profiles would eventually become elliptical, as a result of fault growth evolution that includes both a vertical development and a bilateral propagation. Asymmetrical slip profiles appear when a barrier is encountered along one (half-restricted and tip-restricted profiles, Figs. $2 b, c)$ or both fault tips (double tip restricted (DTR) profiles, Figs. 2d-f). Faults are thus unilaterally propagating or vertically developing, respectively. Steep gradients reflect early arrest in the lateral growth. Finally, the elliptical profiles are interpreted as profiles of faults that are not propagating anymore (Fig. 2g). However, when elliptical profiles show some tapering at one end (Fig. 2h), it is interpreted as the evidence that lateral propagation of the fault has resumed after a phase of vertical growth, after passing the barrier. 


\section{Results}

\subsection{Patterns of Displacement-Length Fault Profiles}

The fault population in the DMH rift is composed of $\sim 40 \%$ of pinned faults, e.g DTR category, of $30 \%$ of propagating faults including either bilateral or unilateral growth, and of $30 \%$ of faults considered to be at their final stage of development, e.g. having an elliptical profile (Fig. 2). In this latter category, the elliptical profiles with tapers $(\sim 17 \%)$ indicate a new phase of lateral growth. It means that about half of the population studied is still in a phase of lateral propagation, while the second half is in a phase of vertical growth (Fig. 2). This analysis also reveals that two third of the 357 faults under study have encountered at least one barrier during their lateral growth (Table 1).

The restricted patterns represent almost half of the fault population under study (Figs. 2d-f and Table 1). Faults with a restricted displacement-length profile show longer and higher scarps than unrestricted faults (Table 1), which is consistent with a later stage of development (Manighetti et al., 2001a). Most of the restricted displacement-length profiles are asymmetrical (88\%, Table 1) and clustered in DTR2 and DTR3 groups (Figs. 2e and f). The steep decrease of slip for the restricted profiles occurs over a distance that is variable, although it never exceeds $20 \%$ of the total length of the fault. DTR3 profiles differ from DTR2 by their steepest gradient: their maximum slip occurs at a distance of $10 \%$ to $20 \%$ of the total fault length, whereas it occurs at one third of the total fault length for DTR2 (Fig. 2e), reflecting a different timing of their meeting with a barrier.

Regarding the profiles consistent with unrestricted patterns, most of them (84\%) correspond to an asymmetric shape, with one steep slip gradient on one side of the fault, e.g. half-restricted or tip-restricted profiles (Figs. $2 \mathrm{~b}$ and c). They are considered as unilaterally propagating and they represent $22.4 \%$ of the total population of 357 faults. The steep gradient of the unrestricted category never affects more than $20 \%$ and $10 \%$ of the total length of the fault for the halfrestricted faults and the tip-restricted, respectively (Figs. $2 b$ and $2 c$ ). Half-restricted faults are twice as more frequent and shorter than tip-restricted ones, and they also show lower $\mathrm{D}_{\max }$ (Table 1). On the contrary, the group of unrestricted profiles consists in a small population (4.2\%) that includes the shortest faults (Figs. 2a and Table 1). This group corresponds to young faults that have small dimensions and that are still bilaterally propagating.

\section{Insert Table 1}

Considering the elliptical category, the proportions of profiles with tapers and those of quasi-elliptical ones are relatively similar. The figure $2 \mathrm{~h}$ shows how variable can be the length of the tapered tip of elliptical patterns, which can represent up to $50 \%$ of the fault length. Although elliptical displacement-length profiles are interpreted to correspond to mature faults, their dimensions (D, L) are smaller than those of the restricted category, which gathers the longest faults with the largest cumulative displacement (Table 1). Even though lengths of unrestricted and elliptical faults are comparable, the maximum displacement for each category differs significantly with larger displacements for the unrestricted category (Table 1). 
In this section, we examine lateral propagation with a focus on tip-restricted and half-restricted patterns, as they both represent a later stage of growth, the bilateral propagation corresponding to the first phase of fault growth (Manighetti et al., 2001a).

Insert Figure 3

The Figure 3 shows the location of the half-restricted and tip-restricted profiles along the DMH rift. For each fault, a symbol (point/square) is indicating which side of the fault is locked and does not propagate anymore. Faults are rather evenly distributed within the axial depression and, to a lesser extent along the rift shoulders, even though they are slightly more numerous at the rift center, in the AVC area (Fig. 3). A small group of mainly northward propagating faults is also observed off-axis, at $\sim 12.3^{\circ} \mathrm{N}$ and at $\sim 9 \mathrm{~km}$ eastward from MSMC. From these observations, it appears that most of the propagating faults are located along the inner floor and within the topographic depression.

The overall spatial distribution of both half-restricted and tip-restricted displacement-length profiles indicates that 63\% of the faults located south of MSMC are southward propagating, whereas $58 \%$ of those located north of MSMC are northward propagating (Fig. 3). In the northern part of the rift, the northward propagating faults are located within the rift topographic depression and do not extend further east than the September 2005 dyke-induced graben. We note that most of the active faults confined within the narrow 2005 graben are propagating southward.

Finally, the off-axis position of the northward propagating faults located east of the MSMC, suggests that these unilaterally propagating faults might have been formed during an earlier phase of $\mathrm{DMH}$ rifting during which the conditions of magma supply were certainly different to now (Ebinger et al., 2013). Such displacement-length profiles

212 detected off-axis, on the eastern part of AVC, could also be interpreted such that this area is still affected by extension processes. We will not discuss further these faults.

\subsection{Growing faults and rift geometry}

216 Here we focus on the influence of magmatic processes on the fault growth, first by considering the distribution of the

217 fault length along the rift, and second by combining these results with observations related to rift geometry.

218 Insert Figure 4.

219 We address such matters by considering all 357 faults regardless of their displacement pattern (Fig. 4): The longest 220 faults $(>3 \mathrm{~km})$ are equally distributed along the borders of the inner floor and the rift shoulders, but $70 \%$ of them are 221 located south of AVC with respect to the small caldera $\left(40.59^{\circ} \mathrm{E}, 12.34^{\circ} \mathrm{N}\right)$ located at the intersection between AVC and 222 DMH rift (Fig. 4). In the rift center and vicinity of AVC, the density of short faults is high. South of AVC, the short 223 faults appear relatively equally distributed along the axial depression and, to a lesser extent, along the rift shoulders.

224 Further north, the short faults are also numerous above the September 2005 dyke-induced graben. 
Insert Figure 5.

In the figure 5, we consider both the inner floor depression and the depression extended to the rift shoulders, to define the first-order rift width. This figure shows that the narrowest part of the whole rift coincides with the intersection of AVC with DMH rift. From there, the rift width broadens towards both rift tips. However, this widening is not similar north and south of AVC. This is even more apparent when the rift shoulders are included in the evaluation of the width of the rift. South of AVC the rift is the largest, $\sim 8 \mathrm{~km}$ (up $\sim 20 \mathrm{~km}$ when rift shoulders are included), whereas the rift width is $\sim 6 \mathrm{~km}$ North of AVC (up to $\sim 8 \mathrm{~km}$, rift shoulders included). The analysis from figures 4 and 5 suggests that at the rift center, where recent and old magma centers are located, the relative large population of short faults concentrates in the narrowest part of the rift. On the contrary, at the rift tips, the axial depression is wider and composed of longer faults. In addition, the faults are more widely distributed in the southern half of the rift (Fig. 4).

\section{Discussion}

Confronting the displacement-length fault profiles with morphological considerations at the scale of the rift points at the interactions between magmatic and tectonic processes at different spatial scales. We have shown that most of the propagating faults are located within the topographic depression, where most of the active extension occurs, mostly accommodated by dyke intrusions (Carbotte et al., 2006; Rowland et al., 2007; Ebinger et al., 2013). In addition, most of the barriers appear to be located towards or in the vicinity of magma storage such as the MSMC, suggesting that faults preferentially propagate away from the magma reservoir. Hence, we suggest that here volcanic centers play a key role on the development and the later evolution of the tectonics structures (Fig. 3). More generally, we have demonstrated the co-location of intense crustal deformation and area of permanent magma storage (Figs. 4-5). In view of these observations, fault growth processes along the DMH rift seem to be controlled by local processes such as magmatism, and not only by regional stress conditions, as it has been proposed for the Asal rift (Fig. 1b, Manighetti et al., 2001a).

As suggested by the topography and geology of the DMH rift (Varet and Gasse, 1978; Vye-Brown et al., 2012), magmatism along DMH rift is the predominant feature (Fig. 1b): the highest elevation at the rift center is associated with the rhyolitic AVC and two volcanoes are located at the northern rift tip: the Dabbahu and Gabho. Both were involved into the transfer of magma below the rift axis during the 2005 dyking event (Wright et al., 2006; Ayele et al., 2009; Grandin et al., 2009). Furthermore, a small caldera, located at the intersection between the rift axis and the AVC, indicates the existence of a magma chamber partly drained about 20 kyrs ago (Fig. 1b; Medynski et al., 2015). Contrary to the caldera and AVC, MSMC does not show any volcanic feature or edifice at the surface and it was only evidenced by geodetic and seismic data (Keir et al., 2009; Hamling et al., 2009, 2010; Grandin et al., 2010a, b; Belachew et al., 
2011). However, MSMC, the small caldera, and AVC, they all are, or have been, associated with the presence of magma storage that has been maintained between $12.28^{\circ} \mathrm{N}$ and $12.4^{\circ} \mathrm{N}$ of latitude during the last $\sim 20$ kyrs (Medynski et al., 2015; Fig. 1b), area that might be extended based on magneto-telluric results. These along-axis variations in the location of magma bodies could reflect a plumbing system composed of short-lived reservoirs, whose positions may vary locally although they remain confined close to the rift center, similar to the localized and transient magma bodies of the second-order slow spreading centers (Cannat et al., 1995; Carbotte et al., 2015). Such distribution of magma at crustal depth participates in making the crust particularly heterogeneous.

More specifically, the presence of magma reservoirs or lenses at shallow depth modifies the thermal field and consequently the temperature-dependent chemical equilibriums in the surrounding crust. The magma-induced thermal anomaly is dissipated by thermal conduction through the upper crust, inducing a thermal softening of the host-rock, which in turn creates a weak layer or a viscoelastic shell (Pavlis, 1996; Burov et al., 2003; Regenauer-Lieb et al., 2008). The thickness of this low-viscosity shell directly relates to the temperature regime of the host-rock, and to the shape and volume of the reservoir (Currenti and Williams, 2014; Douglas et al., 2016 and references therein). The mechanical properties of this weak layer, and more precisely the Young modulus, are significantly decreased when compared to the brittle host-rock (Kampfmann and Berckhemer, 1985; Hobbs et al., 1986). By relaxing the local stresses, this lowviscosity layer induces an increase in the strain-rate along shear zones (Regenauer-Lieb et al., 2008), whereas the brittle

273 host-rock outside the shell keeps accumulating stresses (Currenti and Williams, 2014). The resulting strength contrast

274 between the brittle crust and the viscoelastic shell promotes the conditions of failure in the host rock, hence the 275 localization of the deformation in the upper crust (Benes and Davy, 1996; Callot et al., 2001; Corti, 2003; Buck, 2006; 276 Currenti and Williams, 2014). The shear failure in the host-rock is further enhanced by the presence of a deflating or inflating magma chamber (Gerbault et al., 2012; Currenti and Williams, 2014 and references therein). Therefore, taking into account the probable presence of numerous distinct magma bodies below the region delimited by AVC and MSMC, although some are likely not active anymore, the thermo-mechanical conditions of the upper crust in this area appear highly favorable for the initiation of fault growth (Figs. 4 and 6). In addition, these conditions that facilitate the localization of deformation take place in the narrowest part of the rift (Figs. 4 and 5), where the brittle-ductile transition

282 (BDT) is the shallowest (Grandin et al., 2012). However, the localization of the deformation has probably not been primarily induced by magma bodies such they are currently distributed in the upper crust. Actually the shallow depths

284 of the BDT and the load of a large volcanic edifice such AVC, associated with a weak layer, could have certainly contributed to localize deformation in this area since a long time period according to analog experiments of van Wyk de

286 Vries and Merle (1996). 
considered with respect to the host-rock. These variations make the energy state of the low-viscosity shell higher than

290 the one of the host-rock. More specifically, temperature increase participates in the process of energy dissipation that 291 gives rise to temperature feedback effects, and therefore contributes to strain localization (Regenauer-Lieb et al., 2008).

292 In fact, an increase of temperature causes a decrease of viscosity that generates an increased strain-rate, which in turn 293 produces an increase in temperature (shear heating) and close the loop of self-localizing temperature feedbacks (Hobbs, 294 1986; Regenauer-Lieb et al., 2008). Small temperature perturbations caused for instance, by phase changes or chemical 295 reactions, are sufficient to trigger temperature feedbacks, making them a fundamental instability in the crust, even if 296 they are time dependent and therefore short-term effects (Regenauer-Lieb et al 2008). Thus, such processes can account 297 for a self-sustaining localization of deformation and contribute to maintain crustal heterogeneities even on a relative 298 short-term, both in regions of long-term magma storage and in areas where magma is only temporarily transferred, for 299 instance by dyke intrusions (Fig. 6). In this way, the thin band of southward propagating faults located within the 300 September 2005 dyke-induced graben north of AVC (Fig. 3), may reflect the effect of infrequent intrusions injected 301 from three interacting magma sources (Dabbahu, Gabho and MSMC) under the eastern rift shoulder, as illustrated by 302 the first rifting event in September 2005 (Fig. 3, Wright et al., 2006, Ayele et al., 2009; Grandin et al., 2009), a kind of 303 event that may also have occurred in the past (Fig. 6, Medynski et al., 2016).

304 Although the thermo-mechanical heterogeneities within the brittle crust promote the initiation of faults, they also act as 305 barriers to fault propagation, as illustrated by the only few long faults and conversely, the large number of short faults 306 that are located at the rift center (Fig. 4), as well as by the location of the steepest gradient along the propagating faults 307 (Fig. 3, Manighetti et al., 2004). In addition, the inelastic deformation due to the highly damaged crust located at the 308 fault tips is susceptible to prevent the lateral propagation of the faults (Manighetti et al., 2004). This higher density of 309 barriers located at the rift center is seen both at fault and rift scale (Figs. 3-5). These numerous and various sources of 310 heterogeneities in the upper crust may explain why the elliptical profiles, which have been proposed to correspond to a 311 late stage of fault growth, have smaller dimensions than the restricted ones (Table 1). Indeed, if the elliptical profiles 312 represent mature faults, their conditions of growth along DMH rift may have been somehow laborious, so that both their 313 lateral and vertical development have been inhibited.

314 Conversely, transfers and storage of magma at shallow depth affect less often the rift tips or at greater depths as 315 highlighted in Asal rift (Pinzuti et al., 2010). It makes these areas more stable from a thermo-mechanical point of view. 316 There, the lithosphere is relatively colder, the BDT is up to twice deeper than at the rift center (Fig. 6, Grandin et al., 317 2012) and the rift is wider (Fig. 5). Therefore, the conditions for fault propagation appear more favorable than at the rift 318 center, as shown by the lower density of faults, although longer, at the rift tips, and especially at the southern one (Figs.

3193,4 and 6). We propose that the better localization of deformation observed north of AVC is related to the interaction 320 between the DMH rift and the Dabbahu volcano. 
Finally, the analysis of cumulative-slip profiles combined with geometrical observations are compared to results obtained for a shorter-time scale, during the last rifting episode. Similarly to the propagating faults, the dykes propagated from the magma reservoir towards the rift tips. However, significant differences were detected in the seismicity rates of dykes propagating northward or southward (Belachew et al., 2011; Grandin et al., 2011; Barnie et al., 2015). These observations were interpreted as resulting either from the extensive stresses differently accumulated along the rift (Grandin et al., 2009, 2011; Barnie et al., 2015) or from asperities associated with magma (Belachew et al., 2011). Our long-term analysis revealed in some way comparable results as the brittle deformation is differently localized north and south of AVC-MSMC region. Therefore, we propose that the pre-existing tectonic structures, better localized in the northern part of the rift, could have contributed to a faster propagation of dyke in this area, in addition to other processes suggested (Grandin et al., 2009, 2011; Belachew et al., 2011; Barnie et al., 2015).

\section{Conclusion}

We performed a detailed analysis on displacement-length profiles for 357 faults distributed along the Dabbahu-MandaHararo rift (Afar). Our results suggest that areas under permanent influence of magma bodies gather favorable conditions for initiating faulting (Fig. 6). However, because of the strong heterogeneities that magma bodies generate within the crust, these areas do not offer reliable conditions for efficient lateral propagation of faults. Hence, we find there a majority of short faults. Persistent self-localizing temperature effect is expected where magma is stored and where dykes are injected and faults activated. On the contrary, the deeper brittle-ductile transition and the relative cooler lithosphere near the rift tips are less affected by magma transfers and therefore offer better condition for lateral propagation (Fig. 6), although this might not be the case for the northern extremity of the rift, where the Dabbahu and Gabho volcanoes may interact with normal faults through dyke injections. This analysis shows that the propagating faults keep track of the magma transfers within the crust, suggesting that most of the dykes along the axial depression are mostly fed by the MSMC. On the contrary, the northeastern rift shoulder is mostly intruded by dykes, such as in September 2005, whose magma was provided by the reservoirs of Dabbahu and Gabho volcanoes, even if these events are recognized as unusual.

\section{Acknowledgment}

We thank Harsha Bhat and Raphaël Grandin for fruitful discussions. We are grateful to C. Ebinger and A. Tibaldi for their comprehensive reviews that helped to improve the paper, and to the Editor, C. Passchier for his handling of the manuscript. Most figures were prepared using the Generic Mapping Tool (GMT) software by Wessel and Smith (1991) and Inkscape. This research was supported by the French Agence Nationale pour la Recherche (DoRA project, ANR-09JCJC-0051-01). This is IPGP contribution number 3811. 


\section{References}

Aki, K., 1979. Characterization of barriers on an earthquake fault. Journal of Geophysical Research: Solid Earth, 84(B11), 6140-6148.

Audin, L., Quidelleur, X., Coulié, E., Courtillot, V., Gilder, S., Manighetti, I., ... \& Kidane, T., 2004. Palaeomagnetism and K-Ar and 40Ar/39Ar ages in the Ali Sabieh area (Republic of Djibouti and Ethiopia): constraints on the mechanism of Aden ridge propagation into southeastern Afar during the last 10 Myr. Geophysical Journal International, 158(1), 327-345.

Ayele, A., Jacques, E., Kassim, M., Kidane, T., Omar, A., Tait, S., \& King, G., 2007. The volcano-seismic crisis in Afar, Ethiopia, starting September 2005. Earth and Planetary Science Letters, 255(1), 177-187.

Ayele, A., Keir, D., Ebinger, C., Wright, T. J., Stuart, G. W., Buck, W. R., ... \& Sholan, J., 2009. September 2005 megadike emplacement in the Manda-Harraro nascent oceanic rift (Afar depression). Geophysical Research Letters, 36(20). doi:10.1029/2009GL039605

Barberi, F., \& Varet, J., 1977. Volcanism of Afar: Small-scale plate tectonics implications. Geological Society of America Bulletin, 88(9), 1251-1266.

Barnie, T. D., Keir, D., Hamling, I., Hofmann, B., Belachew, M., Carn, S., ... \& Wright, T., 2015. A multidisciplinary study of the final episode of the Manda Hararo dyke sequence, Ethiopia, and implications for trends in volcanism during the rifting cycle. Geological Society, London, Special Publications, 420, SP420-6.

Belachew, M., Ebinger, C., Coté, D., Keir, D., Rowland, J. V., Hammond, J. O. S., \& Ayele, A., 2011. Comparison of dike intrusions in an incipient seafloor-spreading segment in Afar, Ethiopia: Seismicity perspectives. Journal of Geophysical Research: Solid Earth, 116(B6).

Belachew, M., Ebinger, C., \& Coté, D., 2013. Source mechanisms of dike-induced earthquakes in the Dabbahu-Manda Hararo rift segment in Afar, Ethiopia: implications for faulting above dikes. Geophysical journal international,192(3), 907-917.

Benes, V., \& Davy, P., 1996. Modes of continental lithospheric extension: experimental verification of strain localization processes. Tectonophysics, 254(1), 69-87.

Biggs, J., Amelung, F., Gourmelen, N., Dixon, T. H., \& Kim, S. W., 2009. InSAR observations of 2007 Tanzania rifting episode reveal mixed fault and dyke extension in an immature continental rift. Geophysical Journal International, 179(1), 549-558.

Björnsson, A., Johnsen, G., Sigurdsson, S., Thorbergsson, G., \& Tryggvason, E., 1979. Rifting of the plate boundary in North Iceland 1975-1978. Journal of Geophysical Research, 84(86), 3029-3038.

Bürgmann, R., Pollard, D. D., \& Martel, S. J., 1994. Slip distributions on faults: effects of stress gradients, inelastic deformation, heterogeneous host-rock stiffness, and fault interaction. Journal of Structural Geology,16(12), 1675-1690. Buck, W. R., 2006. The role of magma in the development of the Afro-Arabian Rift System. Geological Society, London, Special Publications, 259(1), 43-54.

Burov, E., Jaupart, C., \& Guillou-Frottier, L., 2003. Ascent and emplacement of buoyant magma bodies in brittle-ductile upper crust. Journal of Geophysical Research: Solid Earth, 108(B4).

Calais, E., d’Oreye, N., Albaric, J., Deschamps, A., Delvaux, D., Déverchere, J., .. \& \& Oyen, A., 2008. Strain accommodation by slow slip and dyking in a youthful continental rift, East Africa. Nature, 456(7223), 783-787. Callot, J. P., Grigné, C., Geoffroy, L., \& Brun, J. P., 2001. Development of volcanic passive margins: Two-dimensional laboratory models. Tectonics, 20(1), 148-159. 
Cannat, M., Mevel, C., Maia, M., Deplus, C., Durand, C., Gente, P., ... \& Reynolds, J. , 1995. Thin crust, ultramafic exposures, and rugged faulting patterns at the Mid-Atlantic Ridge (22-24 N). Geology, 23(1), 49-52. Carbotte, S. M., Detrick, R. S., Harding, A., Canales, J. P., Babcock, J., Kent, G., ... \& Diebold, J., 2006. Rift topography linked to magmatism at the intermediate spreading Juan de Fuca Ridge. Geology, 34(3), 209-212. Carbotte, S. M., Smith, D. K., Cannat, M., \& Klein, E. M., 2015. Tectonic and magmatic segmentation of the Global Ocean Ridge System: a synthesis of observations. Geological Society, London, Special Publications, 420, SP420-5. Cartwright, J. A., Trudgill, B. D., \& Mansfield, C. S., 1995. Fault growth by segment linkage: an explanation for scatter in maximum displacement and trace length data from the Canyonlands Grabens of SE Utah. Journal of Structural Geology, 17(9), 1319-1326. Contreras, J., Anders, M. H., \& Scholz, C. H., 2000. Growth of a normal fault system: observations from the Lake Malawi basin of the east African rift. Journal of Structural Geology, 22(2), 159-168.

Corti, G., Bonini, M., Conticelli, S., Innocenti, F., Manetti, P., \& Sokoutis, D., 2003. Analogue modelling of continental extension: a review focused on the relations between the patterns of deformation and the presence of magma. EarthScience Reviews, 63(3), 169-247.

Courtillot, V., Galdeano, A., \& Le Mouel, J. L., 1980. Propagation of an accreting plate boundary: a discussion of new aeromagnetic data in the Gulf of Tadjurah and southern Afar. Earth and Planetary Science Letters, 47(1), 144-160. Courtillot, V., Armijo, R., \& Tapponnier, P., 1987. Kinematics of the Sinai triple junction and a two-phase model of Arabia-Africa rifting. Geological Society, London, Special Publications, 28(1), 559-573.

Cowie, P. A., \& Scholz, C. H., 1992a. Growth of faults by accumulation of seismic slip. Journal of Geophysical Research, 97, 11085.

Cowie, P. A., \& Scholz, C. H., 1992b. Physical explanation for the displacement-length relationship of faults using a post-yield fracture mechanics model. Journal of Structural Geology, 14(10), 1133-1148.

Cowie, P. A., \& Shipton, Z. K., 1998. Fault tip displacement gradients and process zone dimensions. Journal of Structural Geology, 20(8), 983-997.

Currenti, G., \& Williams, C. A., 2014. Numerical modeling of deformation and stress fields around a magma chamber: Constraints on failure conditions and rheology. Physics of the Earth and Planetary Interiors, 226, 14-27.

Davis, K., Burbank, D. W., Fisher, D., Wallace, S., \& Nobes, D., 2005. Thrust-fault growth and segment linkage in the active Ostler fault zone, New Zealand. Journal of Structural Geology, 27(8), 1528-1546.

Dawers, N. H., Anders, M. H., \& Scholz, C. H., 1993. Growth of normal faults: Displacement-length scaling. Geology, 21(12), 1107-1110.

Dawers, N. H., \& Anders, M. H., 1995. Displacement-length scaling and fault linkage. Journal of Structural Geology, 17(5), 607-614.

Desissa, M., Johnson, N. E., Whaler, K. A., Hautot, S., Fisseha, S., \& Dawes, G. J. K., 2013. A mantle magma reservoir beneath an incipient mid-ocean ridge in Afar, Ethiopia. Nature geoscience, 6(10), 861-865.

de Vries, B. V. W., \& Merle, O., 1996. The effect of volcanic constructs on rift fault patterns. Geology, 24(7), 643-646. Doubre, C., Manighetti, I., Dorbath, C., Dorbath, L., Jacques, E., \& Delmond, J. C., 2007. Crustal structure and magmato-tectonic processes in an active rift (Asal-Ghoubbet, Afar, East Africa): 1. Insights from a 5-month seismological experiment. Journal of Geophysical Research: Solid Earth, 112(B5).

Doubre, C. \& Peltzer, G., 2007. Fluid-controlled faulting process in the Asal Rift, Djibouti, from 8 yr of radar interferometry observations. Geology, 35(1), 69-72.

Douglas, M. M., Geyer, A., Álvarez-Valero, A. M., \& Martí, J., 2016. Modeling magmatic accumulations in the upper crust: Metamorphic implications for the country rock. Journal of Volcanology and Geothermal Research, 319, 78-92. 
Dumont, S., Socquet, A., Grandin, R., Doubre, C., \& Klinger, Y., 2016. Surface displacements on faults triggered by slow magma transfers between dyke injections in the 2005-2010 rifting episode at Dabbahu-Manda-Hararo rift (Afar, Ethiopia). Geophysical Journal International, 204(1), 399-417.

Ebinger, C. J., van Wijk, J., \& Keir, D., 2013. The time scales of continental rifting: Implications for global processes. Geological Society of America Special Papers, 500, 371-396.

Ferguson, D. J., Calvert, A. T., Pyle, D. M., Blundy, J. D., Yirgu, G., \& Wright, T. J., 2013. Constraining timescales of focused magmatic accretion and extension in the Afar crust using lava geochronology. Nature communications,4, 1416. Field, L., Blundy, J., Brooker, R. A., Wright, T., \& Yirgu, G., 2012. Magma storage conditions beneath Dabbahu Volcano (Ethiopia) constrained by petrology, seismicity and satellite geodesy. Bulletin of volcanology, 74(5), 981-1004. Fossen, H., \& Rotevatn, A., 2016. Fault linkage and relay structures in extensional settings-A review. Earth-Science Reviews, 154, 14-28.

Gerbault, M., Cappa, F., \& Hassani, R., 2012. Elasto-plastic and hydromechanical models of failure around an infinitely long magma chamber. Geochemistry, Geophysics, Geosystems, 13(3).

Grandin, R., Socquet, A., Binet, R., Klinger, Y., Jacques, E., de Chabalier, J. B., ... \& Pinzuti, P., 2009. September 2005 Manda Hararo-Dabbahu rifting event, Afar (Ethiopia): constraints provided by geodetic data. Journal of Geophysical Research: Solid Earth, 114(B8).

Grandin, R., Socquet, A., Doin, M. P., Jacques, E., de Chabalier, J. B., \& King, G. C. P., 2010a. Transient rift opening in response to multiple dike injections in the Manda Hararo rift (Afar, Ethiopia) imaged by time-dependent elastic inversion of interferometric synthetic aperture radar data. Journal of Geophysical Research: Solid Earth, 115(B9). Grandin, R., Socquet, A., Jacques, E., Mazzoni, N., de Chabalier, J. B., \& King, G. C. P., 2010b. Sequence of rifting in Afar, Manda-Hararo rift, Ethiopia, 2005-2009: Time-space evolution and interactions between dikes from interferometric synthetic aperture radar and static stress change modeling. Journal of Geophysical Research: Solid Earth, 115(B10).

Grandin, R., Jacques, E., Nercessian, A., Ayele, A., Doubre, C., Socquet, A., ... \& King, G. C. P., 2011. Seismicity during lateral dike propagation: Insights from new data in the recent Manda Hararo-Dabbahu rifting episode (Afar, Ethiopia). Geochemistry, Geophysics, Geosystems, 12(4).

Grandin, R., Socquet, A., Doubre, C., Jacques, E., \& King, G. C., 2012. Elastic thickness control of lateral dyke intrusion at mid-ocean ridges. Earth and Planetary Science Letters, 319, 83-95.

Gudmundsson, A., 2003. Surface stresses associated with arrested dykes in rift zones. Bulletin of Volcanology, 65(8), 606-619.

Gudmundsson, A., \& Loetveit, I. F., 2005. Dyke emplacement in a layered and faulted rift zone. Journal of Volcanology and Geothermal Research, 144(1), 311-327.

Hamling, I. J., Ayele, A., Bennati, L., Calais, E., Ebinger, C. J., Keir, D., ... \& Yirgu, G., 2009. Geodetic observations of the ongoing Dabbahu rifting episode: new dyke intrusions in 2006 and 2007. Geophysical Journal International,178(2), 989-1003.

Hamling, I. J., Wright, T. J., Calais, E., Bennati, L., \& Lewi, E., 2010. Stress transfer between thirteen successive dyke intrusions in Ethiopia. Nature Geoscience, 3(10), 713-717.

Hammond, J. O. S., Kendall, J. M., Stuart, G. W., Keir, D., Ebinger, C., Ayele, A., \& Belachew, M., 2011. The nature of the crust beneath the Afar triple junction: Evidence from receiver functions. Geochemistry, Geophysics, Geosystems, 12(12).

Hayward, N. J., \& Ebinger, C. J., 1996. Variations in the along-axis segmentation of the Afar Rift system. Tectonics, 15(2), 244-257. 
Hobbs, B. E., Ord, A., \& Teyssier, C. , 1986. Earthquakes in the ductile regime? Pure and Applied Geophysics, 124(12), 309-336.

Kampfmann, W., \& Berckhemer, H., 1985. High temperature experiments on the elastic and anelastic behaviour of magmatic rocks. Physics of the earth and planetary interiors, 40(3), 223-247.

Keir, D., Hamling, I. J., Ayele, A., Calais, E., Ebinger, C., Wright, T. J. \& Baker, E., 2009. Evidence for focused magmatic accretion at segment centers from lateral dike injections captured beneath the Red Sea rift in Afar. Geology,37(1), 59-62.

King, G. C. P., 1986. Speculations on the geometry of the initiation and termination processes of earthquake rupture and its relation to morphology and geological structure. Pure and Applied Geophysics, 124(3), 567-585.

Klinger, Y., 2010. Relation between continental strike-slip earthquake segmentation and thickness of the crust. Journal of Geophysical Research: Solid Earth, 115(B7). Doi: 10.1029/2009JB006550

Lahitte, P., Gillot, P. Y., \& Courtillot, V., 2003a. Silicic central volcanoes as precursors to rift propagation: the Afar case. Earth and Planetary Science Letters, 207(1), 103-116.

Lahitte, P., Gillot, P. Y., Kidane, T., Courtillot, V., \& Bekele, A., 2003b. New age constraints on the timing of volcanism in central Afar, in the presence of propagating rifts. Journal of Geophysical Research: Solid Earth, 108(B2).

McClusky, S., R. Reilinger, G. Ogubazghi, A. Amleson, B. Healeb, P. Vernant, J. Sholan, S. Fisseha, L. Asfaw, R. Bendick, et al., 2010. Kinematics of the southern red sea-afar triple junction and implications for plate dynamics. Geophysical Research Letters, 37, L05301.

Makris, J., \& Ginzburg, A., 1987. The Afar Depression: transition between continental rifting and sea-floor spreading. Tectonophysics, 141(1), 199-214.

Manighetti, I., Tapponnier, P., Courtillot, V., Gruszow, S., \& Gillot, P. Y., 1997. Propagation of rifting along the ArabiaSomalia plate boundary: The gulfs of Aden and Tadjoura. Journal of Geophysical Research: Solid Earth, 102(B2), 26812710 .

Manighetti, I., Tapponnier, P., Gillot, P. Y., Jacques, E., Courtillot, V., Armijo, R., ... \& King, G., 1998. Propagation of rifting along the Arabia-Somalia plate boundary: Into Afar. Journal of Geophysical Research: Solid Earth, 103(B3), 4947-4974.

Manighetti, I., King, G. C. P., Gaudemer, Y., Scholz, C. H., \& Doubre, C., 2001a. Slip accumulation and lateral propagation of active normal faults in Afar. Journal of Geophysical Research: Solid Earth (1978-2012), 106(B7), 13667-13696.

Manighetti, I., Tapponnier, P., Courtillot, V., Gallet, Y., Jacques, E., \& Gillot, P. Y., 2001b. Strain transfer between disconnected, propagating rifts in Afar. Journal of Geophysical Research: Solid Earth, 106(B7), 13613-13665.

Manighetti, I., King, G., \& Sammis, C. G., 2004. The role of off-fault damage in the evolution of normal faults. Earth and Planetary Science Letters, 217(3), 399-408.

Manighetti, I., Campillo, M., Bouley, S., \& Cotton, F., 2007. Earthquake scaling, fault segmentation, and structural maturity. Earth and Planetary Science Letters, 253(3), 429-438.

Manighetti, I., Caulet, C., Barros, L., Perrin, C., Cappa, F., \& Gaudemer, Y., 2015. Generic along-strike segmentation of Afar normal faults, East Africa: Implications on fault growth and stress heterogeneity on seismogenic fault planes. Geochemistry, Geophysics, Geosystems, 16(2), 443-467.

Mastin, L. G., \& Pollard, D. D., 1988. Surface deformation and shallow dike intrusion processes at Inyo Craters, Long Valley, California. Journal of Geophysical Research: Solid Earth, 93(B11), 13221-13235.

Medynski, S., Pik, R., Burnard, P., Williams, A., Vye-Brown, C., Ferguson, D., ... \& Calvert, A., 2013. Controls on 
magmatic cycles and development of rift topography of the Manda Hararo segment (Afar, Ethiopia): insights from cosmogenic 3 He investigation of landscape evolution. Earth and Planetary Science Letters, 367, 133-145.

Medynski, S., Pik, R., Burnard, P., Vye-Brown, C., France, L., Schimmelpfennig, I., ... \& Yirgu, G., 2015. Stability of rift axis magma reservoirs: Spatial and temporal evolution of magma supply in the Dabbahu rift segment (Afar, Ethiopia) over the past 30 kyr. Earth and Planetary Science Letters, 409, 278-289.

Medynski S., Pik R., Burnard P., Dumont S., Grandin R., Williams A., Blard P.-H., Schimmelpfennig I., Vye-Brown C., France L., Ayelew D., Benedetti L., Yirgu G. \& ASTER team, 2016. Magmatic cycles pace tectonic and morphological expression of rifting (Afar depression, Ethiopia), Earth and Planetary Science Letters, 446, 77-88. doi:10.1016/j.eps1.2016.04.014.

Mikumo, T., \& Miyatake, T., 1978. Dynamical rupture process on a three-dimensional fault with non-uniform frictions and near-field seismic waves. Geophysical Journal International, 54(2), 417-438.

Muraoka, H., \& Kamata, H., 1983. Displacement distribution along minor fault traces. Journal of Structural Geology, 5(5), 483-495.

Nicol, A., Watterson, J., Walsh, J. J., \& Childs, C., 1996. The shapes, major axis orientations and displacement patterns of fault surfaces. Journal of Structural Geology, 18(2), 235-248.

Nicol, A., Walsh, J. J., Villamor, P., Seebeck, H., \& Berryman, K. R., 2010. Normal fault interactions, paleoearthquakes and growth in an active rift. Journal of Structural Geology, 32(8), 1101-1113.

Nixon, C. W., Sanderson, D. J., Dee, S. J., Bull, J. M., Humphreys, R. J., \& Swanson, M. H., 2014. Fault interactions and reactivation within a normal-fault network at Milne Point, Alaska. AAPG Bulletin, 98(10), 2081-2107.

Pavlis, T. L., 1996. Fabric development in syn-tectonic intrusive sheets as a consequence of melt-dominated flow and thermal softening of the crust. Tectonophysics, 253(1), 1-31.

Peacock, D. C. P., \& Sanderson, D. J., 1991. Displacements, segment linkage and relay ramps in normal fault zones. Journal of Structural Geology, 13(6), 721-733.

Pinzuti, P., Mignan, A., \& King, G. C., 2010. Surface morphology of active normal faults in hard rock: Implications for the mechanics of the Asal Rift, Djibouti. Earth and Planetary Science Letters, 299(1), 169-179.

Pollard, D. D., \& Segall, P., 1987. Theoretical displacements and stresses near fractures in rock: with applications to faults, joints, veins, dikes, and solution surfaces. Fracture mechanics of rock, 277(349), 277-349.

Regenauer-Lieb, K., Rosenbaum, G., \& Weinberg, R. F., 2008. Strain localisation and weakening of the lithosphere during extension. Tectonophysics, 458(1), 96-104.

Roche, V., Homberg, C., \& Rocher, M., 2012. Fault displacement profiles in multilayer systems: from fault restriction to fault propagation. Terra Nova, 24(6), 499-504.

Rowland, J. V., Baker, E., Ebinger, C. J., Keir, D., Kidane, T., Biggs, J., ... \& Wright, T. J., 2007. Fault growth at a nascent slow-spreading ridge: 2005 Dabbahu rifting episode, Afar. Geophysical Journal International, 171(3), 12261246.

Rubin, A. M., \& Pollard, D. D., 1988. Dike-induced faulting in rift zones of Iceland and Afar. Geology, 16(5), 413-417. Rubin, A. M., 1992. Dike-induced faulting and graben subsidence in volcanic rift zones. Journal of Geophysical Research: Solid Earth, 97(B2), 1839-1858.

Scholz, C. H., 2002. The mechanics of earthquakes and faulting. In: Cambridge university press (Eds). Tapponnier, P., Armijo, R., Manighetti, I., \& Courtillot, V. (1990). Bookshelf faulting and horizontal block rotations between overlapping rifts in southern Afar. Geophysical Research Letters, 17(1), 1-4.

Tepp, G., Ebinger, C. J., \& Yun, S. H., 2016. Spectral analysis of dike-induced earthquakes in Afar, Ethiopia. Journal of 
Geophysical Research,121(4), 2560-2574.

Tesfaye, S., Harding, D. J., \& Kusky, T. M., 2003. Early continental breakup boundary and migration of the Afar triple junction, Ethiopia. Geological Society of America Bulletin, 115(9), 1053-1067.

Tibaldi, A., Bonali, F. L., Einarsson, P., Hjartardóttir, Á. R., \& Mariotto, F. P., 2016. Partitioning of Holocene kinematics and interaction between the Theistareykir Fissure Swarm and the Husavik-Flatey Fault, North Iceland.Journal of Structural Geology, 83, 134-155.

Tiberi, C., Ebinger, C., Ballu, V., Stuart, G., \& Oluma, B., 2005. Inverse models of gravity data from the Red Sea-AdenEast African rifts triple junction zone. Geophysical Journal International, 163(2), 775-787.

Varet, J., \& Gasse, F., 1978. Carte géologique de l'Afar central et méridional (Ethiopie et TFAI) au 1/500 000, CNRSCNR, Geotechnip. La Celle Saint-Cloud.

Vigny, C., Huchon, P., Ruegg, J. C., Khanbari, K., \& Asfaw, L. M., 2006. Confirmation of Arabia plate slow motion by new GPS data in Yemen. Journal of Geophysical Research: Solid Earth, 111(B2).

Vye-Brown, C., Medynski, S., Smith, K. B., Field, L., \& Wright, T., 2012. Geological map of the Dabbahu (MandaHararo) Rift, North, 1: 100,000 scale. British Geological Survey.

Wessel, P., \& Smith, W. H., 1991. Generic mapping tools. EOS, 72, 441.

Walsh, J. J., \& Watterson, J. (1988). Analysis of the relationship between displacements and dimensions of faults. Journal of Structural Geology, 10(3), 239-247.

Wright, T. J., Ebinger, C., Biggs, J., Ayele, A., Yirgu, G., Keir, D., \& Stork, A., 2006. Magma-maintained rift segmentation at continental rupture in the 2005 Afar dyking episode. Nature, 442(7100), 291-294.

Wright, T. J., Sigmundsson, F., Pagli, C., Belachew, M., Hamling, I. J., Brandsdóttir, B., ... \& Calais, E., 2012.

Geophysical constraints on the dynamics of spreading centres from rifting episodes on land. Nature Geoscience, 5(4), $242-250$.

Figure 1: (a) Afar Depression with the different propagating rift segments corresponding to the branches of the triple junction with the Red Sea extending from the North, the Gulf of Aden ridge penetrating the depression from the SW and the East African Rift Systems in the South. Direction of propagation (arrow symbols) is indicated after the tectonic model from Manighetti et al. (1998, 2001b). (b) The 357 faults studied are mapped along Dabbahu-Manda-Hararo rift. The lateral extension of the shallow magma chamber (MSMC) involved in the 2005-2010 rifting episode is proposed after Grandin et al. (2010b). The Ado'Ale silicic (AVC) complex forms a volcanic chain transverse to the rift axis. Distinct directions of extension result from Vigny et al. (2006) and McClucsky et al. (2010) models (indicated closed to the vectors) but only those obtained from McClucsky et al. 2010 show a small change along the rift as they consider the relative motion between the Nubia plate and the Danakil microplate.

7 Figure 2: Distribution of displacement-length profiles for the 357 normal faults studied along the Dabbahu-Manda- 
Hararo rift following the classification of Manighetti et al. (2001a). These eight shapes are split into three categories of faults: the unrestricted ones which are uni- or bilaterally propagating (a-c), the restricted faults which are pinned faults characterized by a vertical growth phase (d-f), and the elliptical faults (g-h). See text for more details.

Figure 3: (a) Location of faults with half and tip restricted displacement-length profiles along the Dabbahu-MandaHararo rift. The high slip gradients along the faults are indicated by a circle and a square for the tip-restricted and the half-restricted profiles, respectively. Faults in black propagate northward, while red faults propagate southward. In background, the topography is shown with contour lines every $30 \mathrm{~m}$. The borders of the topographic depression are indicated by purple and gray lines ( $\mathrm{a}$ and $\mathrm{b}$ respectively), and the September 2005 dyke-induced graben boundaries in light gray lines (a) and in red shading (b). The red star locates the current shallow reservoir MSMC involved in the 2005-2010 rifting episode. The red fill circle (b) locates the Dabbahu volcano reservoir. (b) Interpretative scheme showing the directions of lateral propagation deduced from the half-restricted and tip-restricted profile patterns.

Figure 4: Distribution of the length for the 357 faults studied, all patterns included. The first three colors represents faults with length shorter than 1,2 and $3 \mathrm{~km}$ respectively. The red star indicates the position of the most recent shallow reservoir MSMC and the gray dotted lines the borders of the topographic depression. The small caldera is located by a red circle. The caldera separates faults located north and south of AVC.

Figure 5: (a) Spatial evolution of the rift width based on the geometry of the axial topographic depression (straight lines) or the topographic depression extended to the rift shoulders (dashed lines). The background represents the DEM (with contour lines every $30 \mathrm{~m}$ ) and the 357 faults considered in this study. The red stars correspond to the current and shallow magma reservoirs. (b) Interpretation of the spatial variations of the rift width, with the narrowest area (orange circle) matching with the intersection between DMH rift and AVC that is under the permanent influence of magmatic processes.

Figure 6 : Conceptual model illustrating the influence of magma on fault propagation. Some displacement-length profiles are indicated with a dot showing the steepest gradient associated with the first barrier encountered during the lateral propagation of the faults. Orange shading shows the 2005 dyke intrusion. The DMH rift is split into 3 sectors reflecting the fault behaviors with respect to magmatic processes. The circular black arrows indicate where selflocalizing temperature feedbacks are expected. The brittle-ductile transition (BDT) is indicated after Grandin et al. 
630 (2012). Below the figure, are detailed the faulting processes that are hindered (in blue), while in red are those that are 631 promoted.

632

633

634

635 Table 1: Characteristics of the fault classified into the eight categories presented in Figure 2. $\mathrm{L}_{\text {mean }}$ and $\mathrm{D}_{\text {mean }}$ for mean 636 length and mean maximum displacement respectively; $\mathrm{L}_{\text {med }}$ and $\mathrm{D}_{\text {med }}$ for median length and median maximum 637 displacements; « std » for standard deviation, « $\mathrm{N} »$ refers to the number of faults considered.

638

639

640 


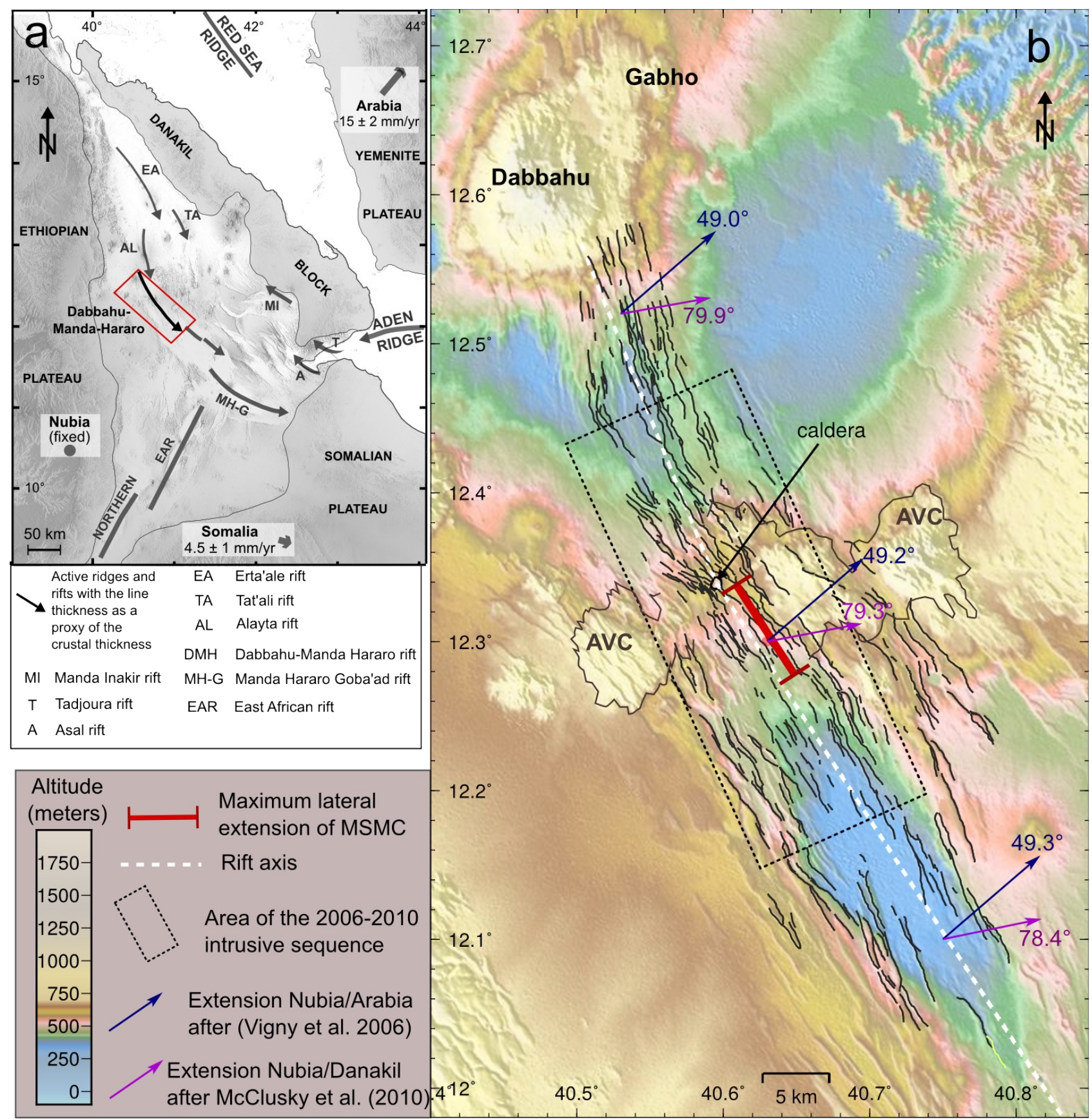




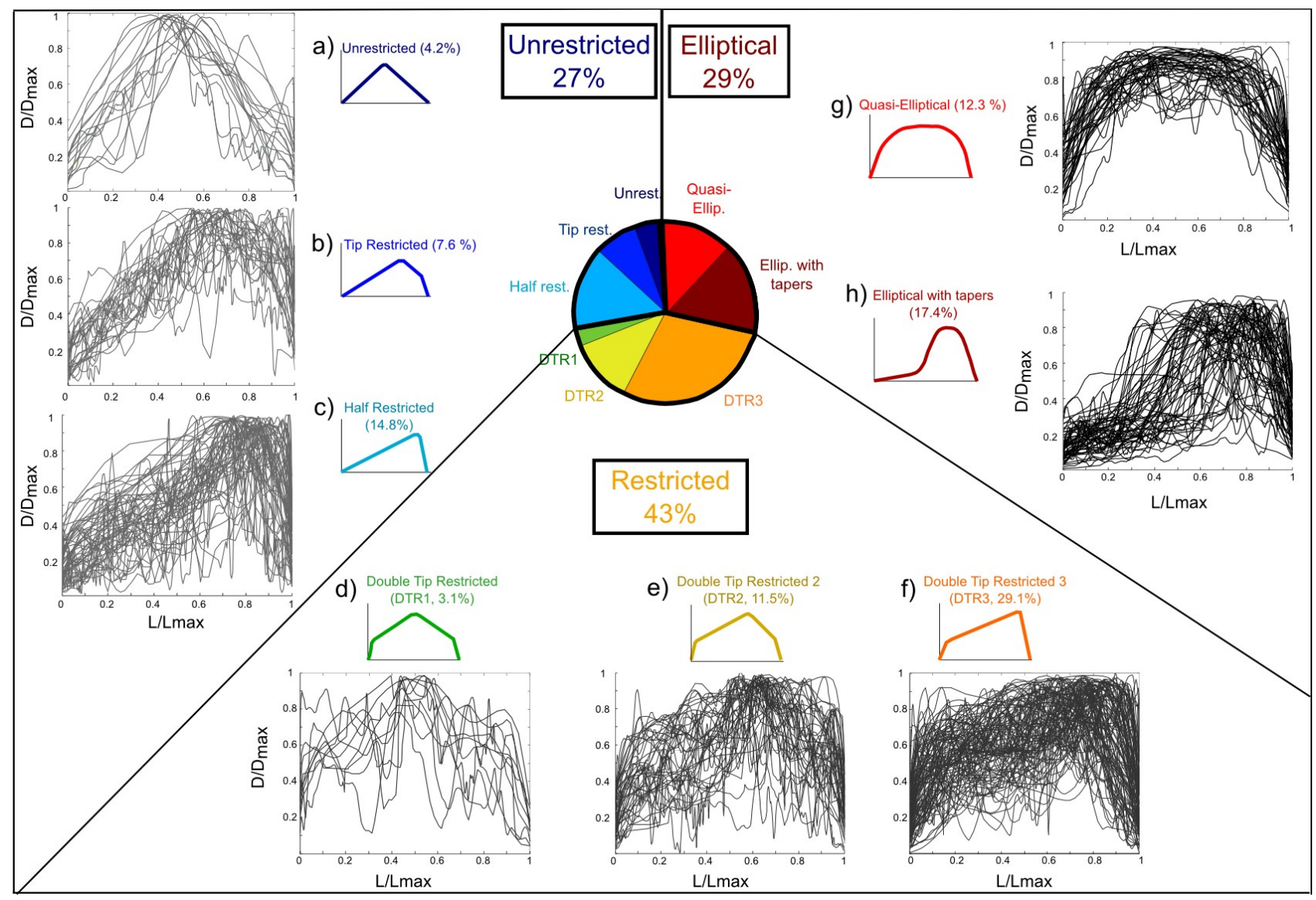




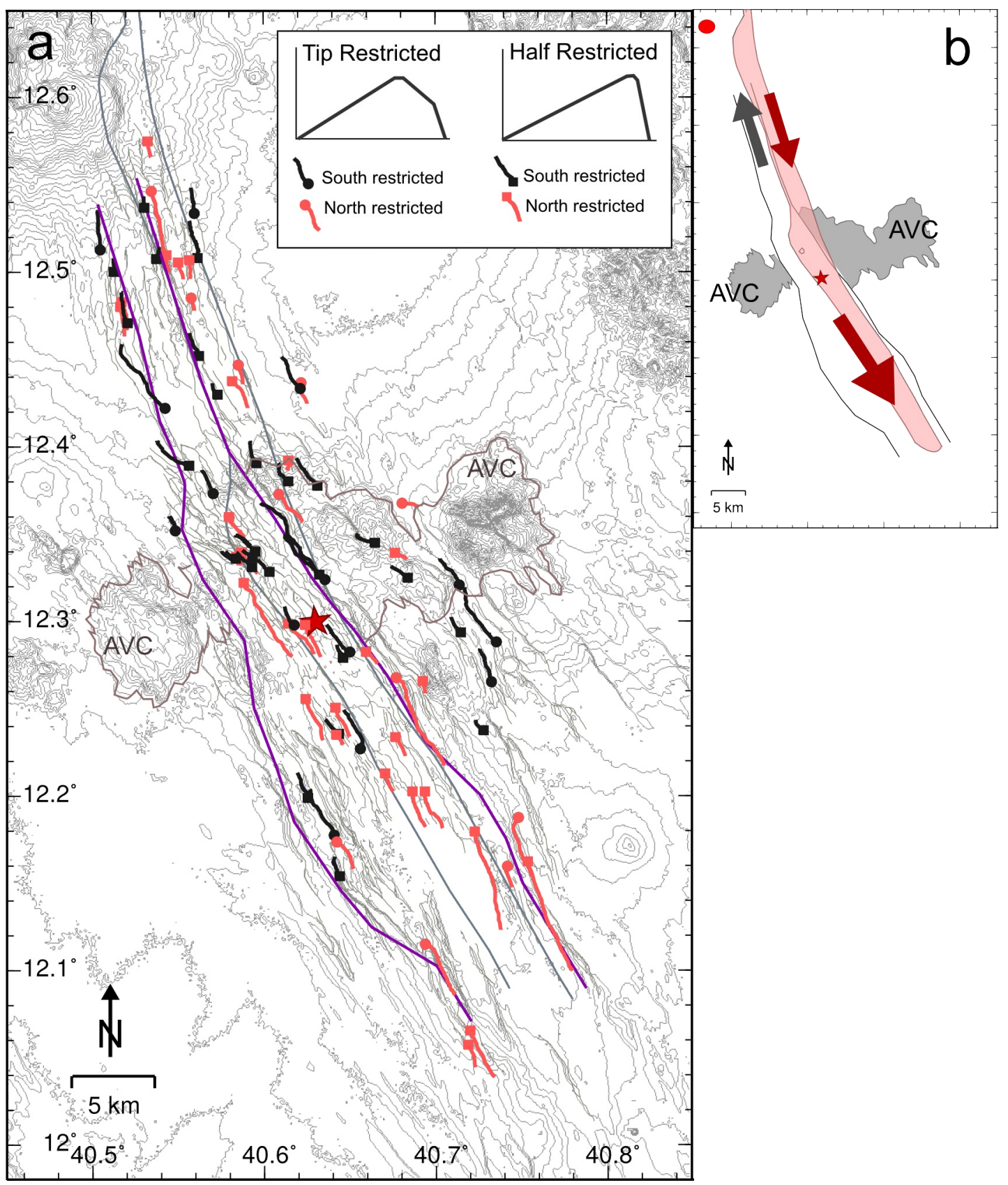

0

991

2




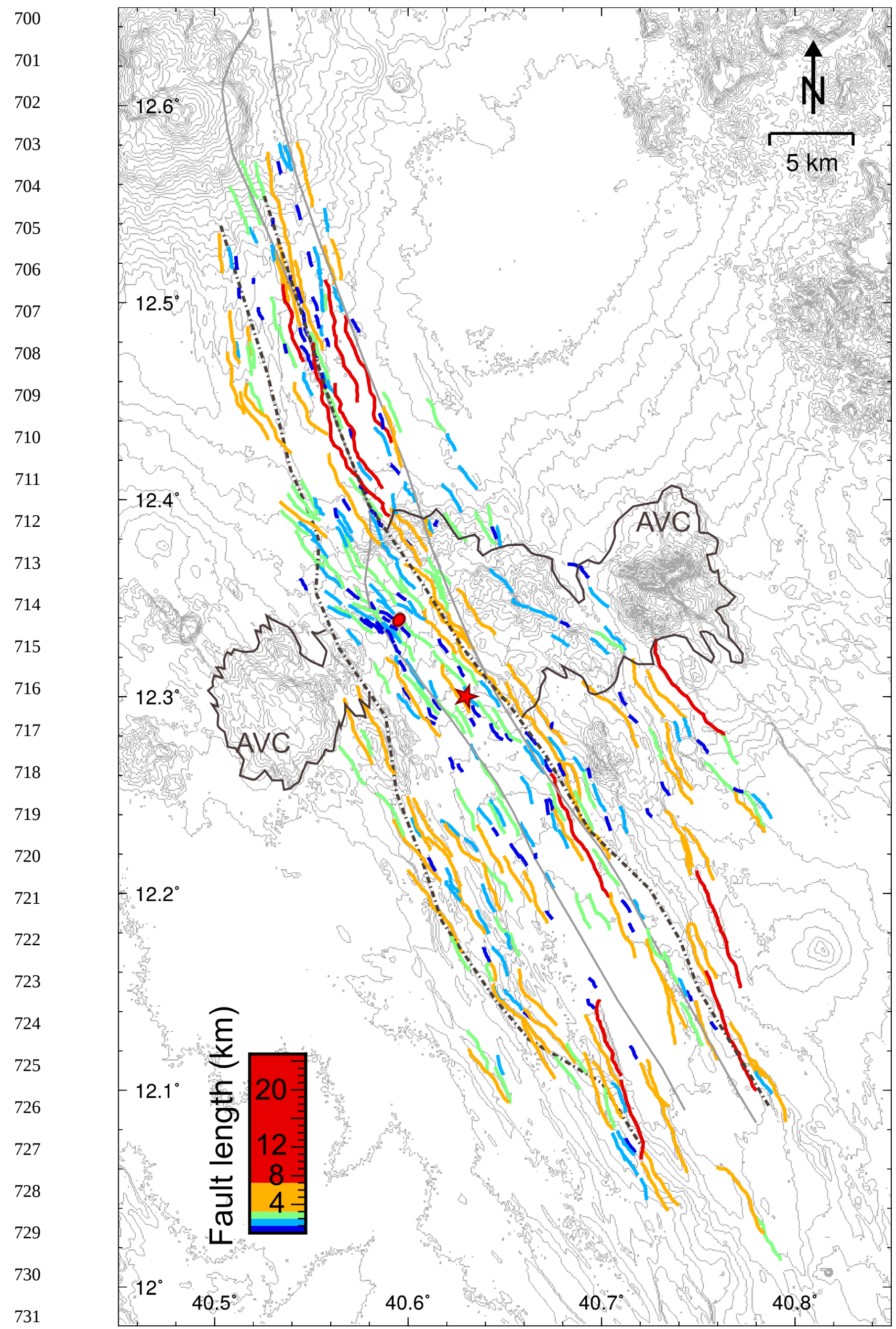




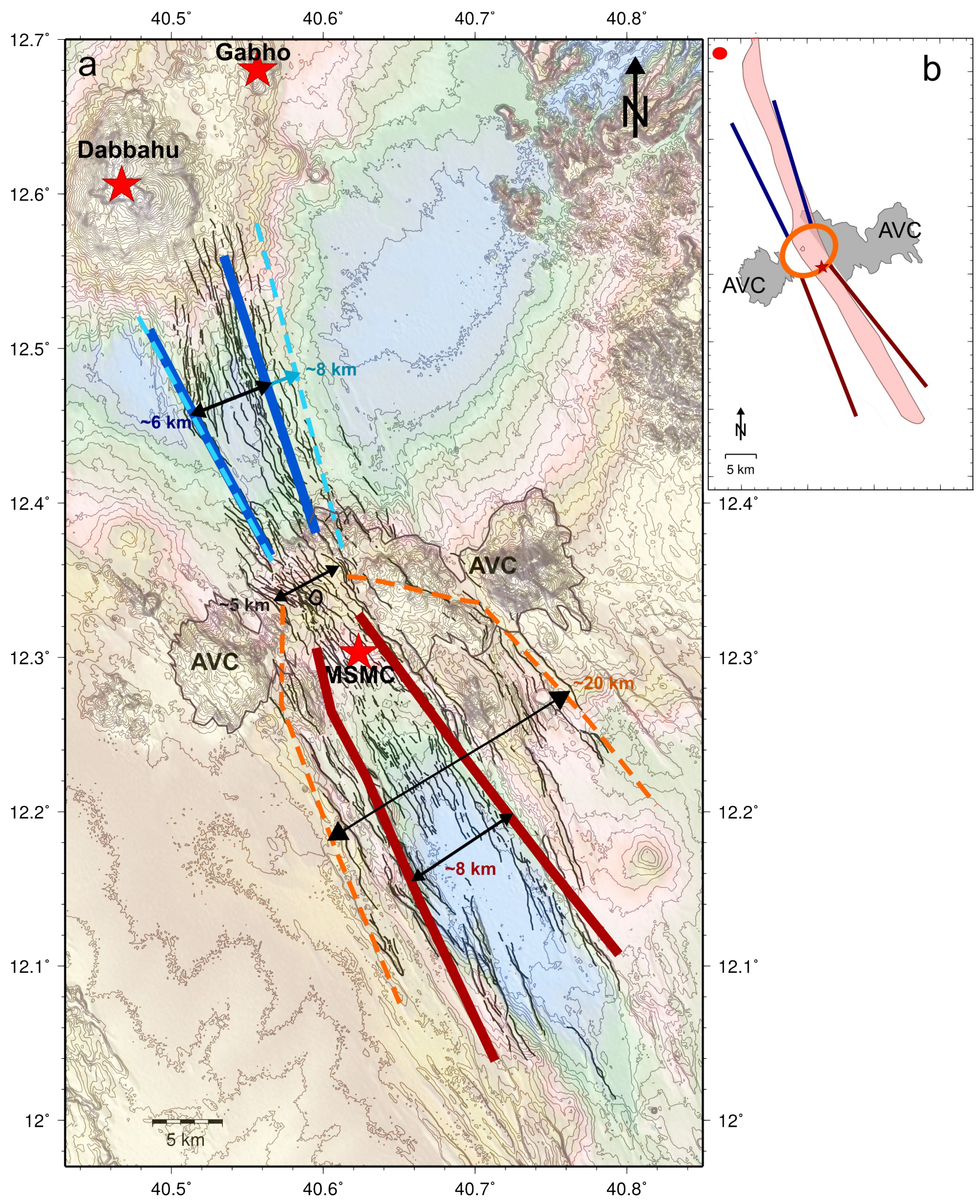




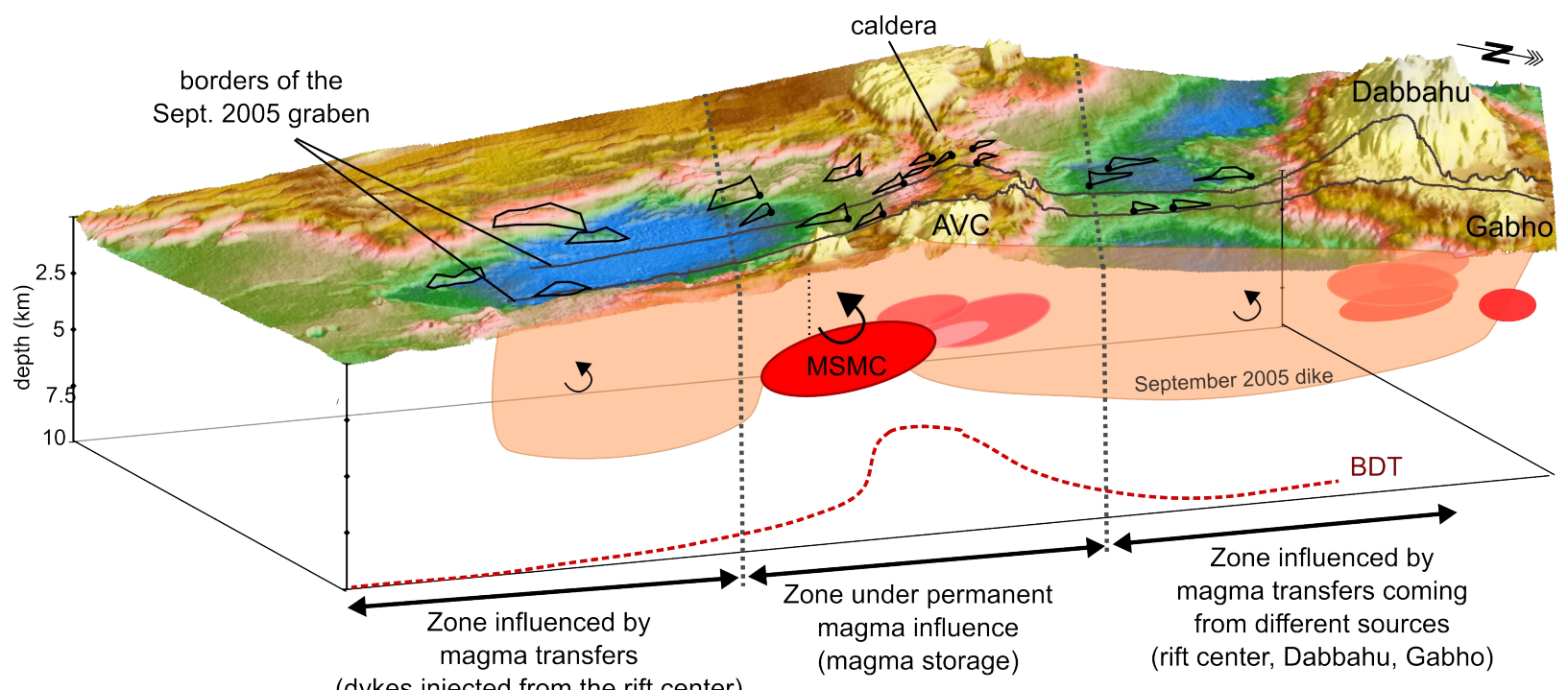

Enhanced processes: Fault propagation

Repressed processes: Initiation of fault growth

Initiation of fault growth

Fault propagation 